\title{
Restrukturisasi Budaya Hukum Kejaksaan Dalam Penuntutan Sebagai Independensi di Sistem Peradilan Pidana Indonesia
}

\author{
Appludnopsanji $i^{1 *}$, Pujiyono ${ }^{2}$ \\ ${ }^{1,2}$ Fakultas Hukum Universitas Diponegoro, Semarang, Indonesia \\ E-mail: appludnopsanji96@gmail.com
}

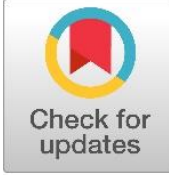

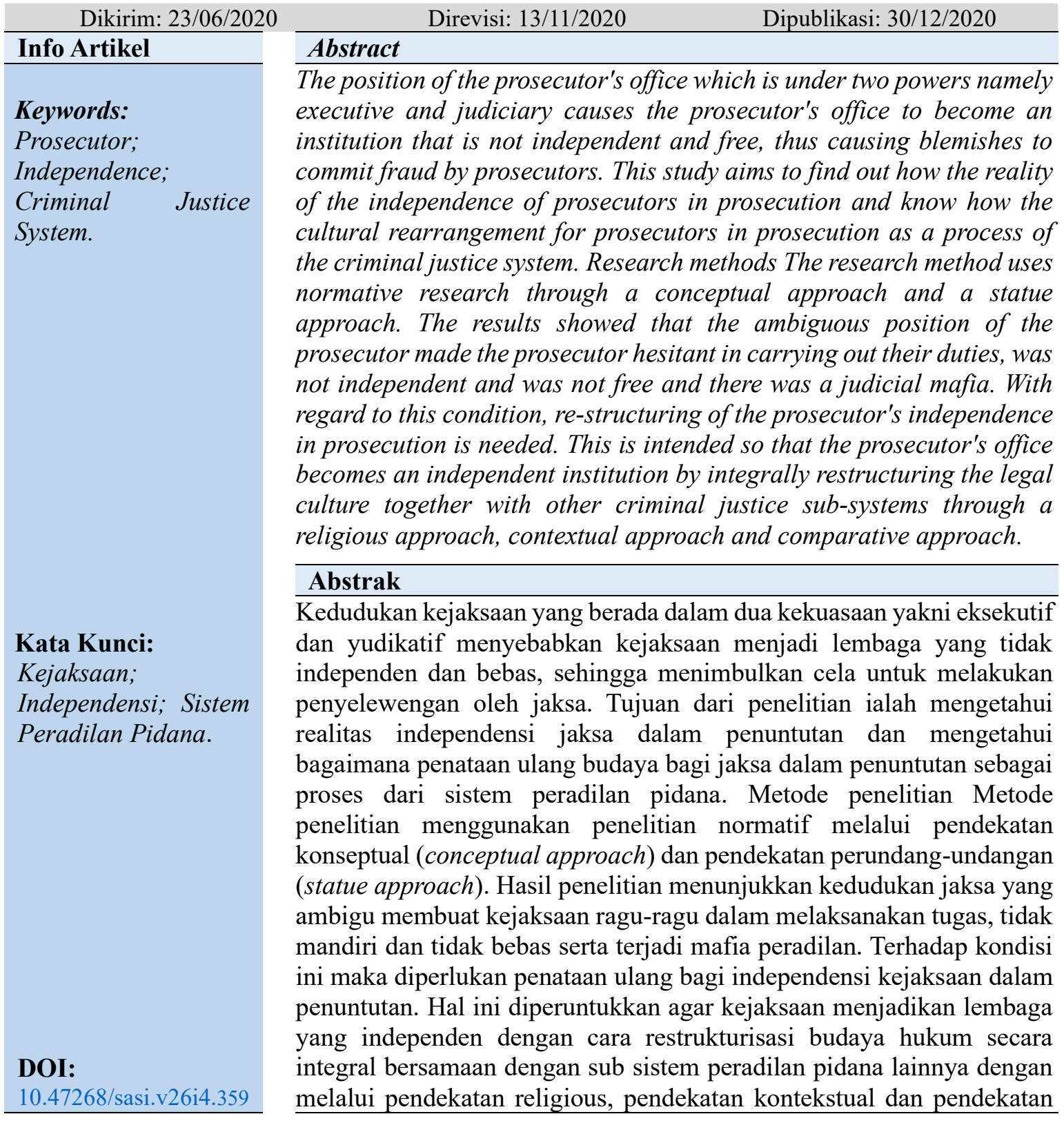




\section{A. PENDAHULUAN}

Keselurahan sistem yang didalamnya terdapat bagian-bagian yang saling terkoneksi satu dengan lainnya disebut sebagai sistem peradilan pidana. ${ }^{1}$ Hal penting dalam sistem peradilan pidana yakni terdapat sub sistem penuntutan yang dilakukan oleh Kejaksaan Republik Indonesia. Kejaksaan Republik Indonesia sebagai lembaga negara yang berperan sebagai aparat penegak hukum dengan mejalankan fungsinya yang mempunyai wewenang sebagai penuntut umum, pelaksanaan putusan pengadilan serta wewenang lain yang diatur dalam undang-undang kejaksaan dalam koridor sebagai aparat penegak hukum. Jaksa memiliki peranan penting dalam persidangan dan jaksapunlah yang diberi wewenang oleh undang-undang untuk melakukan penuntutan sebagai penuntut umum yang bertindak atas nama Negara dalam menjalankan tugas dan wewenangannya. Lembaga kejaksaan republik Indonesia merupakan lembaga Negara yang dikomandoi oleh seorang jaksa agung yang dipilih dan bertanggung jawab kepada Presiden sebagai kepala Negara dan kepala pemerintahan. Sistem komando ini menitikberatkan adanya unsur hierarki dalam instansi kejaksaan bertujuan untuk memudahkan dalam menjalankan tugas dan fungsinya. Selain jabatan-jabatan yang struktural yang ada dalam kejaksaan, terdapat juga lembaga tempat bekerja dari instansi kejaksaan yang tersebar di seluruh provinsi dan berbagai kabupaten/kota guna merangkul setiap permasalahan hukum yang ada dikalangan masyarakat. $^{2}$

Secara yuridis dan faktual, sub sistem kejaksaan dalam sistem peradilan pidana memang mempunyai fungsi penegakan hukum, akan tetapi tidak bernaung dalam satu atap kekuasaan yudikatif. Pasal 2 ayat 1 Undang-Undang Nomor 16 tahun 2004 tentang kejaksaan menyatatakan jika kejaksaan republik Indonesia merupakan lembaga pemerintahan yang melaksanakan kekuasaan Negara dibidang penuntutan serta kewenangan lain berdasarkan undang-undang. Terhadap posisi kejaksaan sebagai penegak hukum yang tidak bertitik utama pada lembaga yudikatif melainkan masuk pada ranah eksekutif juga, kondisi ini dapat menyebabkan tugas utama dari kejaksaan yakni melakukan penuntutan disinyalir tidak akan bersifat independen.

Pada saat melaksanakan tugas, jaksa haruslah bebas dan tidak terikat dari intervensi kekuasaan pemerintah atau kekuasaan lain demi terciptanya tujuan hukum seperti keadilan, kepastian hukum serta kemanfaatan didalamnya dengan mengalihkan norma agama, kesopanan, kesusilaan serta harus mencari dan menemukan nilai-nilai yang hidup didalam masyarakat. ${ }^{3}$ Peran jaksa sebagai penuntut umum harus tidak diikutcampurkan pada kekuasaan manapun supaya dapat mencapai tujuan dalam penegakan hukum dan bisa digiring untuk menjalankan tugas berdasarkan aturan yang berlaku supaya terwujudnya supremasi hukum, melindungi kepentingan umum, menegakan hak asasi manusia serta pemberantasan korupsi kolusi dan nepotisme. ${ }^{4}$ Posisi jaksa pada peradilan pidana sangat menentukan nasib dari terdakwa karena jaksa sebagai penuntut umum merupakan jembatan penghubung antara tahap penyidikan dengan peradilan. Hal ini didasari paa doktrin hukum

1 Muntaha, M. (2017). "Pengaturan Praperadilan dalam Sistem Hukum Pidana di Indonesia”. Mimbar Hukum-Fakultas Hukum Universitas Gadjah Mada, 29 (3): 461-473.

2 Sumakul, A. E. (2018). "Independensi Kejaksaan Dalam Melakukan Penyidikan Tindak Pidana Korupsi Menurut Undang-Undang Nomor 31 Tahun 1999 Jo. Undang-Undang Nomor 20 Tahun 2001”. Lex Crimen, 7 (5): 159-166.

3 Anwar Yesmil \& Adang. (2011). Sistem Peradilan Pidana. Bandung: Widya Padjadjaran, h. 204.

4 Ibid, h. 202. 
yang mejelaskan bahwa penuntut umum punya hak monopoli penuntutan. Maksudnya, seseorang baru bisa diadili bila terlebih dahulu dengan adanya tuntutan pidana dari penuntut umum. Oleh karena itu lembaga kejaksaan sebagai penuntut umum berwenang dalam menuntut terdakwa di sidang pengadilan. ${ }^{5}$

Sebagai komponen dari sistem peradilan pidana, kejaksaan dituntut untuk selalu menjaga independensinya dari campur tangan pihak manapun termasuk eksekutif. Namun nampaknya kejaksaan akan sulit untuk terbebas dari campur tangan eksekutif karena secara struktural, kejaksaan berada di bawah kekuasaan eksekutif. Bagaimana pun juga, Jaksa Agung sebagai pemimpin lembaga kejaksaan secara struktural harus tunduk kepada atasannya, yaitu Presiden sebagai pemegang tertinggi kekuasaan eskekutif. Akibat kedudukan kejaksaan yang masih ada ikut campurnya Negara dalam lembaga kejaksaan menimbulkan independensi jaksa diragukan oleh masyarakat. Kedudukan jaksa yang masuk dalam lembaga eksekutif dan masuk juga dilembaga yudikatif dalam penegakan hukum tidak cukup menguatkan kemandirian jaksa dalam melaksanakan penegakan hukum khususnya di bidang penuntutan. Banyak kehawatiran terjadi apabila ada oknum-oknum dari lembaga eksekutif yang melakukan tindak pidana maka jaksa yang melakukan penuntutan tidak diberi kekuasaan mutlak dalam melaksanakan tugasnya. ${ }^{6}$ Hal ini akan berpengaruh ke budaya hukum dari jaksa itu sendiri yang tidak bebas, terikat serta rentan terjadinya penyelewengan tugasnya seperti terjadinya jual beli tuntutan perkara, jual beli perkara, penghentian penyidikan dengan dalil uang dan terjadinya mafia peradilan didalamnya. Berdasarkan hal diatas untuk menjamin keindependesinya jaksa dibidang yudikatif dalam sistem peradilan pidana yang dtuntut untuk bebas dan tanpa campur tangan dari pihak manapun maka diperlukan pembaharuan atau penataan ulang atau restrukturisasi lembaga kejaksaan dalam budaya hukum sehingga bisa tetap menjaga independesi jaksa dalam melaksanakan tugasnya. Sehingga artikel ini akan membahas mengenai restrukturisasi budaya hukum kejaksaan dalam menjamin independesi jaksa di sistem peradilan pidana, namun sebelumnya dalam tulisan ini akan dipaparkan mengenai realitas budaya hukum yang buruk dari kejaksaan dalam hal penuntutan sehingga bisa dilakukan penataan ulang dimasa yang akan datang.

Ada penelitian terdahulu yang pernah meneliti tentang lembaga kejaksaan, diantaranya telah dilakukan oleh: 1) Kevin Stiffan Sigar pada tahun 2017 dengan fokus kajian mengenai kemandirian kejaksaan dalam sistem ketatanegaraan republik Indonesia. ${ }^{7}$ 2) Didit Ferianto Pilok pada tahun 2013 dengan focus kajian mengenai kedudukan dan fungsi jaksan dalam sistem peradilan pidana menurut KUHAP. ${ }^{8}$ 3) Ismail Ghonu pada tahun 2015 dengan fokus kajian mengenai independensi kejaksaan dalam sistem perailan pidana di Indonesia. ${ }^{9}$ Berdasarkan dari penelitian sebelumnya, penelitian ini memiliki kesamaan tema mengkaji mengenai independensi kejaksaan dalam sistem peradilan pidana namun, penelitian kali ini lebih berfokus kepada penataan kembali/restrukturisasi budaya dari lembaga kejaksaan dalam penuntutan demi terjaganya independensi jaksa dalam sistem peradilan pidana. Adapun tujuan dari penelitian ini adalah untuk memaparkan seperti apa realitas lembaga

5 Kristiana Yudi. (2011). Independensi Kejaksaan dalam Penyidikan Korupsi. Bandung: Citra Aditya Bakti, h. 52.

${ }^{6}$ Rosita, D. (2018). "Kedudukan Kejaksaan Sebagai Pelaksana Kekuasaan Negara di Bidang Penuntutan dalam Struktur Ketatanegaraan Indonesia”. Jurnal Ius Constituendum, 3 (1): 27-47. DOI: http://dx.doi.org/10.26623/jic.v3i1.862

7 Sigar, K. S. (2017). "Kemandirian Kejaksaan Dalam Sistem Ketatanegaraan Republik Indonesia (Kajian UU No. 16 Tahun 2004)". Lex et Societatis, 5 (5).

8 Pilok, D. F. (2013). “Kedudukan Dan Fungsi Jaksa Dalam Peradilan Pidana Menurut Kuhap”. Lex Crimen, 2 (4).

9 Ghonu, I. (2015). “Independensi Kejaksaan Dalam Sistem Peradilan Pidana Di Indonesia”. Justitia Et Pax, 31 (2). DOI: https://doi.org/10.24002/jep.v31i2.1342 
kejaksaan dalam penegakan hukum saat ini dan memberikan suatu konsep baru berupa usulan mengenai rekontruksi budaya hukum bagi kejaksaan sehingga tetap terjaganya independensi jaksa dalam melaksanakan tugas dan fungsinya.

\section{B. METODE PENELITIAN}

Adapun penelitian ini berspesifikasi pada sifat yang deskriptif-analitis dengan jenis penelitian doktrinal atau yuridis normatif. Penelitian deskriptif-analitis dimaksudkan untuk menggambarkan, menelaah dan menjelaskan permasalahan yang ingin dikaji yaitu terkait reformasi sistem peradilan pidana Indonesia dimasa yang akan datang. Pendekatan penelitian yang digunakan adalah pendekatan peraturan perundang-undangan yang mengacu pada peraturan perundang-undangan Indonesia yang didalamnya yakni Undang-Undang Kejaksaan. Penelitian ini bertumpu pada data sekunder berupa bahan hukum primer, bahan hukum sekunder dan bahan hukum tersier yang diperoleh melalui studi kepustakaan sebagai teknik pengumpulan datannya, yang kemudian dianalisis menggunakam teknik analisis kualitatif untuk mendapatkan kesimpulan yang sebenarnya

\section{PEMBAHASAN}

\section{Realitas Independensi Lembaga Kejaksaan Dalam Penuntutan Di Sistem Peradilan Pidana}

Lembaga pemerintah yang melakukan kekuasaan Negara dibidang penuntutan salah satunya yaitu Kejaksaan. Penuntutan yang diemban tugas dari seorang jaksa memiliki tugas secara aktif mengajukan berkas perkara kepada pengadilan (hakim). Secara umum, Kejaksaan Republik Indonesia sebagai lembaga pemerintah mempunyai fungsi dan kewenangan dalam bidang penegakan hukum serta kewenangan yang berhubungan dengan menjaga ketertiban dan ketenteraman. Terhadap fungsi penegakan hukum kejaksaan dibidang hukum pidana telah diuraikan dalam aturan perundang-undangan kejaksaan di Pasal 30 ayat 1 UU kejaksaan yang menjelaskan bahwa adapun tugas dan kewenangannya diantara adanya penuntutan yang telah mempunyai hukum yang tetap, adanya pengawasan pada pelaksanaan putusan pidana bersyarat, keputusan lepas yang bersyarat, adanya perlakukan penyidikan pada tindak pidana tertentu berdasarkan perundang-undangan, pelengkapan berkas perkara dan dapat melakukan pemeriksaan tambahan pada suatu berkas sebelum dilimpahkan ke pengadilan yang daam ekseskusinya dikoordinsaikan dengan penyidik. $^{10}$

Penuntutan merupakan serangkaian tindakan yang dilakukan guna melakukan pelimpahan berkas suatu perkara ke pengadilan yang berwenang yang dijalankan oleh penuntut umum agar berkas yang dilanjutkan pemeriksaan di pengadilan untuk diperiksa dan diputus oleh hakim. ${ }^{11}$ Hukum positif Indonesia mengatur mengenai penuntutan hanya dilaksanakan kepada lembaga penuntut dalam hal ini penuntut umum yang berkesesuaian dengan asas dominus litis yang punya peran strategis dalam menentukan dapat tidaknya diteruskannya sebuah kasus sampai di pengadilan. Lembaga penuntut umum sendiri bisa berasal dari kejaksaan dan KPK. Penuntut umum dari KPK membidangi penuntutan secara khusus dalam perkara korupsi sedangkan penuntut umum dari kejaksaan membidangi penuntutan untuk semua jenis tindak pidana kecuali tindak pidana militer oleh Oditur Militer. $^{12}$

\footnotetext{
10 Pasal 30 ayat 1 Undang-undang Nomor 16 tahun 2004 tentang Kejaksaan

11 Pasal 1 ayat 7 Kitab Undang-undang Hukum Acara Pidana

12 Arrsa, R. C. (2014). "Rekonstruksi Politik Hukum Pemberantasan Korupsi Melalui Strategi Penguatan
} 
Lembaga penuntutan kejaksaan yang berinduk dalam satu organisasi lembaga kejaksaan, dalam pemahamannya mengenai tugas dan kewenangannya dalam pasal 2 ayat 1 sampai dengan 3 Undang-undang Nomor 16 tahu 2004 tentang Kejaksaan menunjukkan bahwa posisi dari lembaga kejaksaan tergolong dilematis karena mengahadapi keadaan dual obligation, yakni disatu sisi sebagai penegak hukum yang mengemban tugas berkenaan dengan kekuasaan penuntutan yang harus bersikap independen terbebas dari segala intervensi dari pihak manapun termasuk eksekutif (Presiden) disisi lain sebagai pejabat Negara (anak buah Presiden) dalam konteks manajemen pemerintahan dengan jaksa agung yang harus mempunyai loyalitas tinggi kepada pemerintahan. ${ }^{13}$ Posisi dilematis inipun dapat terpengaruh terhadap independensi kejaksaan dalam penuntutan sebagai upaya penegakan hukum dalam sistem peradilan pidana.

Independensi oleh kejaksaan sangat dibutuhkan dalam upaya penegakan hukum yang berintegritas dan mengembalikan kepercayaan publik terhadap buruknya sistem penegakan hukum di Indonesia saat ini. Independensi sendiri mengandung arti kebebasan, kemandirian, kemerdekaan atau tidak berada dibawah kendali/pengawasan dari lembaga lain. ${ }^{14}$ Kejaksaan sebagai aparat penegak hukum yang masuk kepada kekuasaan kehakiman harus merdeka dan mandiri dalam melaksanakan setiap proses penegakan hukum di kekuasaan kehakiman. Kekuasaan kehakiman sendiri harus diperluas bukan hanya menyangkut dibadan peradilan namun disetiap elemen dari proses penegakan hukum mulai dari penyidikan, penuntutan, pengadilan, pelaksana pidana. Oleh karena itu dalam menjalankannya kekuasaan kehakiman harusnya bersifat independensi yang terintegral.

Konsekuensi dari pola pikir akal mengenai kedudukan kejaksaan sebagai aparat pemerintahan menunjukkan bakwa kejaksaan diragukan independensinya, merupakan bawahan pemerintah hingga adanya kerjasama kepada kekuasaan pemerintahan. Alhasil, dampaknya menjelaskan bahwa penegakan hukum yang dilaksanakan tugasnya oleh kejaksaan tidak dapat mencapai suatu kemandirian. Sebagai contoh akibat tidak independensi jaksa dalam Kasus penyelesaian Bibit dan Chandra yang diakhiri dengan SKP2 (Surat Ketetapan Penghentian Penuntutan) dan pernyataan atau sikap jaksa agung yang memilih menunggu turunnya izin pemeriksaan kepala daerah dari presiden untuk memeriksa kepala daerah yang telah ditetapkan sebagai tersangka, meskipun perundang-undangan memungkinkan dilakukan pemeriksaan tanpa izin dari presiden asalkan telah 60 hari sejak izin diterima dan izin juga belum turun. ${ }^{15}$ Besarnya pengaruh subordinat lembaga kejaksaan terhadap presiden (pemerintah) berakibat tidak memungkinkan aktifitas penegakan hukum lepas dari pengaruh kekuasaan eksekutif. Penghentian penuntutan juga pernah dilakukan oleh jaksa dalam kasus dugaan korupsi Bantuan Likuidasi Bank Indonesia (BLBI). Saat itu jaksa agungnya yaitu jaksa Urip, walaupun dalam perjalanan proses perkaranya ditemukan kemudian bukti-bukti oleh KPK yang memberhentikan penuntutan oleh jaksa agung itu menerima suap sehingga dikeluarkannya Surat Penghentian Penyidikan Perkara (SP3). ${ }^{16}$ Selain kasus-kasus yang menimpa jaksa dalam penegakan hukum yang bertitik singgung

Penyidik Dan Penuntut Umum Independen KPK”. Jurnal Rechts Vinding: Media Pembinaan Hukum Nasional, 3 (3): 381-396.

13 Pujiyono. (2012). Rekonstruksi Sistem Peradilan Pidana Indonesia. Semarang: Penerbit Pustaka Magister, h. 107.

14 Arief, B. N. (2019). Kapita Selekta Hukum Pidana Tentang Sistem Peradilan Pidana Terpadu. Semarang: Bahan Penerbit Universitas Diponegoro, h.36.

15 Muhammad, M. (2019). "Pemeriksaan Kepala Daerah Yang Terlibat Dalam Tindak Pidana Korupsi”. Jurnal Yustitia, 18 (1), h. 47-60.

16 Saputra, F., Kalo, S., Mulyadi, M., \& Hamdan, M. (2014). “Analisis Yuridis Penerbitan Surat Perintah Penghentian Penuntutan oleh Kejaksaan Dikaitkan dengan Asas Oportunitas dan Undang-undang No 16 Tahun 2004 Tentang Kejaksaan RI”. USU Law Journal, 2 (1): 105-123. 
dengan lembaga eksekutif, ada juga kasus-kasus yang dilakukan oleh oknum jaksa dalam menghaluskan tindak pidana yang dilakukan tersangka sebut saja terjadinya mafia peradilan yang dilakukan oleh jaksa dalam penegakan hukum seperti mantan jaksa Kejari Yogyakarta Eka Safitra dan jaksa Kejari Surakarta Satriawan Sulaksono yang didakwa telah menerima suap Rp 200 juta dari proyek saluran air di Yogyakarta, kasus mantan Asisten Pidana Khusus (Aspidsus) Kejaksaan Tinggi (Kejati) Jawa Tengah, Kusnin, didakwa menerima suap sebesar 294 ribu dolar Singapura dari Alfin Suherman dalam penanganan kasus kepabeaan. Keduanya menerima duit dari pengusaha kontraktor PT Widoro Kandang bernama Gabriella Yuan Anna Kusuma dan Mantan Kepala Kejaksaan Negeri (Kajari) Pamekasan Rudi Indraprasetya didakwa menerima Rp 250 juta dari Sutjipto Utomo selaku Kepala Inspektorat Kabupaten Pamekasan. Uang suap itu diberikan agar Rudi menghentikan pengumpulan data dan bahan keterangan terkait kasus dugaan penyelewengan dana desa di Desa Dasok, Pamekasan. ${ }^{17}$

Perbuatan curang itu dilakukan oleh oknum jaksa yang biasanya menggunakan modus melakukan pemerasan, perpanjangan rentan waktu penyidikan yang dilakukan guna merundingkan uang damai, surat panggilan tanpa status tersangka atau saksi, yang pada akhirnya akan dimintakan uang supaya statusnya tidak naik menjadi tersangka. Kemudian melakukan negosiasi, pelepasan tersangka melalui SP3 dengan membuat dakwaan yang sifatnya kabur sehingga terdakwa diputus bebas oleh majelis hakim, penggelapan perkara karena terdakwa merupakan keluarga pejabat, tawar menawar penuntutan, peringanan penuntutan dan lain-lain. ${ }^{18}$

Berdasarkan kasus-kasus diatas bila dikaji ketentuan dari Pasal 2 Jo. Pasal 18 dan Pasal 19 Undang-undang Nomor 16 tahun 2004 yang menempatkan lembaga kejaksaan dalam posisi yang tidak mandiri dan bersifat ambigu baik dari segi pertanggungjawaban kepada atasan maupun dalam kekuasaan kehakiman sehingga berdampak pada tindakan-tindakan penegakan hukum yang sering ragu, tidak tegas dan bahkan terjadinya penyelewengan kekuasaan dengan menerima suap. Perbuatan-perbuatan jaksa yang telah menyimpang ini menunjukkan bahwa adanya budaya hukum dari jaksa yang sudah terkikis dengan keindahan uang yang dapat menyelesaikan semua perkara olehnya. Budaya hukum menjadi unsur yang krusial dalam memahami perbedaan-perbedaan yang terletak pada sistem hukum yang satu dengan yang lainnya. Kultur hukum bertalian erat dengan masalah nilai, kesadaran hukum dan perilaku masyarakat yang berimplikasi pada bekerjanya hukum. ${ }^{19}$

Lawrence M. Friedman membagi berbagai komponen dalam membentuk budaya hukum kedalam 3 (tiga) bagian yakni: struktur, substansi dan kultur. ${ }^{20}$ Apabila dikaitkan dengan sistem hukum di kejaksaan maka komponen sturur berkenaan dengan kelembagaan kejaksaan yang ingin diciptakan itu seperti jaksa yang bebas korupsi, independen dan mandiri sehingga dengan adanya patokan/tujuan yang ingin dicapai itu maka lembaga kejaksaan dapat menerapkan dan dijadikan patokan agar dalam menjalankan tugas harus berintegritas, jujur dan patuh. Komponen substansi adalah aspek isi dari sistem hukum itu sendiri yang didalamnya termaksud norma-norma dalam perwujudan peraturan perundang-

17 Medistiara, Yulida - detikNews, Deretan Jaksa yang Malah Diadili Karena Kasus Korupsi, diakses pada tanggal 6 Juni 2020 dalam https://news.detik.com/berita/d-4994630/deretan-jaksa-yang-malah-diadilikarena-kasus-korupsi

18 Widodo, J. P. (2012). "Reformasi Sistem Peradilan Pidana dalam Rangka Penanggulangan Mafia Peradilan”. Jurnal Dinamika Hukum, 12 (1): 108-120.

19 Yusyanti, D. (2015). "Strategi Pemberantasan Korupsi Melalui Pendekatan Politik Hukum, Penegakan Hukum Dan Budaya Hukum". E-Journal Widya Yustisia, 1 (1): 87-97.

20 Jainah, Z. O. (2011). "Membangun Budaya Hukum Masyarakat Penegak Hukum dalam Pemberantasan Tindak Pidana Narkotika”. Keadilan Progresif, 2 (2): 123-136. 
undangan. Di lembaga kejaksaan dengan adanya dual obligation yang terjadi maka dibutuhkan suatu rekonstruksi dari segi substansi guna menjadikan lembaga kejaksaan yang mandiri dan bebas dalam penegakan hukumnya. Sedangkan komponen kultur merupakan nilai-nilai dan sikap-sikap yang merupakan pengikat dari sistem serta menentukan tempat sistem itu ditengah budaya bangsa, seperti kesadaran hukum masyarakat dalam penegakan hukumnya. Dalam kultur di lembaga kejaksaan maka dibutuhkan kesadaran hukum dari jaksa dimulai dari peraturan-peraturan hukum yang mengikat, badan pembuat undangundangn, badan pelaksana hukum/sanksinya, masyarakatnya, dalam hal ini kesadaran dari jaksanya dan lain-lain. $^{21}$

\section{Restrukturisasi Budaya Hukum Dalam Independensi Kejaksaan Dalam Penuntutan Terhadap Sistem Peradilan Pidana Di Indonesia}

Restrukturisasi dimaknai sebagai arti untuk penataan kembali. Pada kaitannya dengan penataan kembali ini, dengan demikian artian restrukturisasi erat kaitannya terhadap rekonstruksi yaitu membangun kembali sistem penegakan hukum pidana di Indonesia. Sehingga, istilah resrtrukturisasi dan rekonstruksi ini muara ujungnya serupa yakni untuk menata kembali. ${ }^{22}$ Restrukturisasi ataupun rekonstruksi sistem peradilan pidana dalam hal ini tidak sekedar diarahkan untuk membangun kembali, dan tetapi bertujuan membentuk bangunan baru yang lebih baik dalam arti menciptakan sistem peradilan pidana lebih modern dan berguna serta mengembalikkan kembali kepercayaan masyarakat terhadap penegakan hukum saat ini. ${ }^{23}$

Penataan kembali untuk sistem peradilan pidana Indonesia sejatinya diperuntukkan untuk menata kembali sistem penegakan hukum pidana disebabkan oleh proses peradilan yang intinya ada pada proses menegakkan hukum. ${ }^{24}$ Sehingga identik dengan sistem kekuasaan kehakiman karena kekuasaan kehakiman pada dasarnya merupakan kekuasaan/kewenangan menegakkan hukum. Menegakkan kekuasaan kehakiman dalam sistem peradilan pidana haruslah merdeka dan mandiri atau artian langsung bahwa kekuasaan kehakiman dalam menjalankan tugasnya harus independen. Independensi kekuasaan kehakiman pada hakikatnya merupakan kemandiran pada semua kekuasaan penegakan hukum sebagai satu kesatuan, jadi bukan kemandirian yang fragmenter/parsial tetapi kemandirian yang integral dalam suatu sistem. Kemandirian yang integral dalam kekuasaan kehakiman ini dimaksudkan yakni independensi didalam suatu sistem, dimana di sebuah sistem terdapat didalamnya sub-sub sistem. Sub-sub sistem yang termaksud pada sistem peradilan pidana meliputi sub sistem penyidikan, sub sistem penuntutan, sub sistem peradilan dan sub sistem pelaksana putusan/pidana. ${ }^{25}$

Pada sub sistem bagian penuntutan yang dilakukan kejaksaan dalam sistem peradilan pidana tetap memiliki interdependensi dari kejaksaan sendiri meskipun dalam sistem sistem

21 Al-Azhar, H. F. (2019). "Rekonstruksi Konseptual Peradilan sebagai Revitalisasi Kekuasaan Kehakiman dalam Sistem Ketatanegaraan Indonesia”. Volksgeist: Jurnal Ilmu Hukum dan Konstitusi, 2 (1): 39-51.

22 Arief, B. N. (2017). RUU KUHP Baru Sebuah Restrukturisasi/Rekonstruksi Sistem Hukum Pidana Indonesia. Semarang: Badan Penerbit Universitas Diponegoro, h. 1.

${ }^{23}$ Muhammad, R. (2009). "Kemandirian Pengadilan Dalam Proses Penegakan Hukum Pidana Menuju Sistem Peradilan Pidana Yang Bebas Dan Bertanggung Jawab". Jurnal Hukum IUS QUIA IUSTUM, 16 (4): 463-478. DOI: https://doi.org/10.20885/iustum.vol16.iss4.art2

24 Arief. B. N. (2019). Reformasi Sistem Peradilan Sistem Penegakan Hukum Di Indonesia. Semarang: Bahan Penerbit Universitas Diponegoro, h. 2.

25 Ali, M. (2007). "Sistem Peradilan Pidana Progresif; Alternatif dalam Penegakan Hukum Pidana". Jurnal Hukum Ius Quia Iustum, $14 \quad$ (2): $210 \quad$ - $229 . \quad$ DOI: https://doi.org/10.20885/iustum.vol14.iss2.art2 
peradilan pidana haruslah terintegrasi dengan berbagai sub sistem yang ada. Hal ini diperuntukkan agar setiap bagian dari sistem itu memiliki kekuasaan sendiri yang bebas dan mandiri dalam tugas dan wewenangnya. Semua kegiatan yang merupakan bagian dari sistem peradilan pidana yang terintegrasi itu haruslah dibawah koordinasi dan kendali pimpinan puncak dari sistem peradilan pidana. Dengan demikian rekonstruksi yang akan ditata kembali merupakan permasalahan yang komplek dan harus dilakukan dengan secara integral dan tidak boleh parsial, adapun proses penataan kembali dari sub sistem penuntutan oleh kejaksaan dalam hal melakukan penuntutan agar terciptanya independensi jaksa meliputi 3 (tiga) factor, dimulai dari factor hukum/substansi hukum, factor kelembagaan/struktur huku dan factor budaya hukum dari jaksa maupun masyarakat. Selain restrukturisasi dibidang substansi hukum, struktur hukum maka ada hal yang juga penting guna menjadikan seorang jaksa yang berintegritas, independen, bebas dan mandiri dialah strukturisasi di bidang budaya hukum.

Pada point akhir dari factor-faktor yang dapat mempengaruhi penegakan hukum oleh Soerjono soekanto adalah faktor budaya. Faktor budaya yang dimaksud disini merupakan factor budaya hukum yang membentuk suatu karakter atau output dari hukum yang dibuat oleh pemerintah dan dijalankan oleh masyarakat berdasarkan karsa manusia didalam pergaulannya. ${ }^{26}$ Aspek budaya hukum dalam sistem peradilan pidana merupakan perwujudan dari sistem nilai-nilai budaya hukum itu sendiri. Permasalahan budaya hukum di kejaksaan dapat dilhat dari maraknya oknum jaksa yang bermain kotor dan masalah optimalisasi budaya/orientasi keilmuan dalam penegakkan hukum. Barda Nawawi Arief dalam bukunya reformasi sistem peradilan pidana menjelaskan lunturnya ataupun bergesernya kualitas keilmuan dari aparat penegak hukum karena sudah bergesernya orientasi mereka dalam penegakkan hukum. Fenomena ini dapat dilihat dari adanya budaya amplop atau budaya permainan tercela oleh penegak hukum yang semakin hari diresahkan oleh masyarakat. Selanjutnya, berkenaan dengan masalah kecenderungan aparat penegak hukum yang berfikir hukum secara parsial dan hanya melihat ketentuan pidana berdasarkan undang-undang saja tapi melihat hukum yang hidup didalam masyarakat dan kondisi eksternal pelaku dalam melakukan tindak pidana. ${ }^{27}$

Berkaitan dengan faktor budaya hukum, sebagaimana dikatakan oleh Friedman kalau legal culture adalah unsur dari sikap dan nilai social yang ada dibagian budaya, kebiasaankebiasaan, pendapat-pendapat, cara melakukan pekerjaan dan cara berpikir. Menurutnya dapat dikatakan bahwa budaya hukum ialah pengenjawantahan dari sikap manusia kepada hukum, kepercayaan dalam sistem hukum, nilai-nilai, pemikiran, dan terlepas dari harapan. Dengan istilah lain menjelaskan jika budaya hukum adalah hasil pikiran sosial dan kekuatan sosial yang menentukan bagaimana hukum digunakan, dihindari dan disalahgunakan oleh manusia. Tidak adanya kultur hukum maka sistem hukum dianggap tidak punya daya layaknya ikan mati yang terhempas dikeranjang. Lawrence M. Friedman membedakan budaya hukum terbagi atas integral legal culture yang berkenaan dengan kultur hukum lawyer dan judged's dan external legal culture yakni kultur hukum masyarakat pada umumnya. ${ }^{28}$ Kultur hukum pada konteks penegakan hukum mempunyai fokus terhadap nilai-nilai filosofinya dari hukum, nilai-nilai yang hidup didalam masyarakat dan kesadaran/sikap perilaku sosialnya, serta pendidikan ilmu hukum. Dengan mengacu kepada

26 Windari, R. A. (2011). "Penegakan Hukum Terhadap Perlindungan Anak Di Indonesia (Kajian Normatif Atas Bekerjanya Hukum Dalam Masyarakat)". Media Komunikasi FPIPS, 10 (1). DOI: http://dx.doi.org/10.23887/mkfis.v10i1.1174

27 Ansori, L. (2018). "Reformasi Penegakan Hukum Perspektif Hukum Progresif". Jurnal Yuridis, 4 (2): 148-163. DOI: http://dx.doi.org/10.35586/.v4i2.244

28 Teubner, G. (Ed.). (2011). Dilemmas of law in the welfare state (Vol. 3). Walter de Gruyter. 
pemaknaan dari kultur hukum bagi penegak hukum tersebut maka restrukturisasi/rekonstruksi yang harus ditata ulang memuat tentang gagasan, ide atau konsep hukum yang dilakukan dengan pengorganisasian kembali bersama dengan legal substance dan legal structure.

Pembaharuan budaya hukum dengan mencakup hal yang lebih komprehensif dan optimal dalam penataan ulang di budaya hukum sebagaimana telah diusung oleh Barda Nawawi Arief diantaranya ada tiga pendekatan keilmuan secara integral, diantaranya: dengan menggunakan pendekatan religious, pendekatan kontekstual dan pendekatan melalui perbandingan hukum. Pendekatan religious merupakan pendekatan utama dalam membentuk budaya hukum penegak hukum agar tetap independen, jujur, dan berintegritas. ${ }^{29}$ Pendekatan religious ini berorientasi pada pedoman ilmu dari hukum pidana dan tuntunan tuhan/religious dalam menegakkan hukum pidana. Tuntunan itu mengandung empat prinsip diantaranya prinsip persamaa (equality/non-discrimination), prinsip objektivitas (tidak subjektif), prinsip tidak pilih kasih (non-favoritisme/non-nepotisme), dan prinsip tidak berpihak (fairness/impartial). Pendekatan konstekstual dimaksudnkan dalam melaksanakan penegakan hukum pidana yang berlandaskan hukum positif tetapi menjalankannya juga dalam konteks Sistem Hukum Nasional (SISKUMNAS) yang berorientasi pada nilai-nilai Pancasila, UUD 1945, dan rambu-rambu umum dari proses penegakan hukum seperti UU Kekuasaan Kehakiman. Sedangkan pendekatan komparatif/perbandingan dipergunakan untuk melihat bagaimana Negara lain dalam mengatur mengenai hukum pidananya sendiri dan proses penegakkan hukumnya. Hal ini diperuntukkan dalam pembaharuan hukum pidana dalam pembentukan peraturan perundang-undangan. Penegak hukum sebagai penegakan system nilai tentu harus cepat menyesuaikan diri dengan laju perkembangan nilai baik secara local, nasional Maupin nilai-nilai global dengan wujud dapat meresapi perkembangan nilai-nilai yang ada sehingga penegakan hukum yang akan dilaksanakan nantinya dapat diterima oleh masyarakat.

Berdasarkan gagasan-gagasan yang telah diungkapkan diatas, kejaksaan dalam hal ini tergolong dari bagian system peradilan pidana setidaknya dapat menerapkan gagasan yang telah diuraikan. Pembaharuan budaya hukum bagi kejaksaan dapat menjadikan lembaga kejaksaan tetap mandiri, bebas, jujur serta menjadikan kejaksaan sebagai lembaga yang progresif. Satjipto rahardjo menjelaskan bahwa progresivme bertolak dari pandangan kemanusiaan yang menyatakan bahwa manusia pada hakekatnya adalah baik, memiliki sifat kasih sayang serta kepedulian antar sesama. ${ }^{30}$ Sifat progresif inilah yang merupakan unsur penting dari pembentukan karakter bagi aparat penegak hukum agar nantinya dalam menegakkan hukum tidak hanya terpaku pada teks perundang-undangan melainkan melihat unsur moral kemanusiaan yang ada pada penegak hukum seperti kejaksaan. Kehadiran hukum progresif dalam penegakan hukum Indonesia tidak hanya dapat mengandalkan kepastian hukum tetapi dapat melihat aktualisasi hukum yang ada didalam masyarakat. Ketika ideology para penegak hukum hanya bersandarkan pada kepastian hukum maka akan sulit ditemukan keadilan sebab kepastian hukum erat dengan keinginan untuk mempertahankan status quo. Sehingga sebagai aparat penegak hukum harus memandang hukum secara dinamis namun tetap besandar pada peraturan perundang-undangan. ${ }^{31}$ serta menjadikan penegakan hukum yang berkemanusiaan dan dapat menggunakan hati nurani dalam menghukum pelaku tindak pidana.

29 Op Chit, Arief. B. N. Kapita Selekta Hukum Pidana Tentang Sistem Peradilan Pidana Terpadu, h. 52.

30 Rahardjo, Satjipto 2009. Hukum Progresif Sebuah Sintesa Hukum Indonesia. Yogyakarta: Genta Publishing, h. 17.

31 Rahardjo, Satjipto 2011. Satjipto Rahardjo Dan Hukum Progresif Urgensi Dan Kritik. Jakarta: Epistema Institue, h. 218. 


\section{PE N T U P}

Restrukturisasi budaya kejaksaan sebagai independensi dalam penuntutan pada sistem peradilan pidana saat ini dinilai sangat perlu mengingat kondisi lembaga kejaksaan dalam penegakan hukum saat ini dinilai masyarakat kurang direspon baik dengan banyaknya kasuskasus yang menimpa jaksa dalam melaksanakan tugasnya. Realitas independensi kejaksaan dalam penuntutan saat ini dipengaruhi kedudukan kejaksaan yang merupakan sebagai lembaga pemerintahan yang harus bertanggung jawab kepada pemerintah dan sebagai lembaga yudikatif dalam kekuasaan kehakiman. Kedudukan yang dilematis ini berpengaruh kepada kemandirian kejaksaan dalam melaksanakan tugas. Fakta menyatakan bahwa dengan kondisi seperti ini jaksa tidak bisa menjalankan tugasnya dengan baik yang berdampak pada keragu-raguan jaksa dalam penegakan hukumnya, diragukan kemandiriannya serta rentan akan campur tangan dari pihak pemerintah dalam melaksanakan tugas. Selain kedudukan jaksa yang menjadi problematika, budaya hukum jaksa yang buruk seperti bermain kotor dalam perkara, terjadinya praktik mafia peradilan serta keilmun hukum yang sifatnya parsial. Atas hal-hal tersebut diperlukan suatu penataan kembali atau restrukturisasi terhadap lembaga kejaksaan. Restrukturisasi meliputi aspek substansi hukum, struktur hukum dan budaya hukum. Restrukturisasi budaya hukum di lembaga kejaksaan diperlukan agar dapat mengubah pola pikir serta penanaman nilai-nilai hukum yang telah bergeser sebelumnya. Restrukturisasi budaya kepada aparat penegak hukum dalam hal ini kejaksaan dapat dilakukan dengan menggunakan tiga pendekatan diantaranya pendekatan religious, pendekatan kontekstual dan pendekatan perbandingan. Cara-cara tersebut dipergunakan agak kedepannya aparat penegak hukum dalam tetap terjada independensinya, bebas serta menjadikan aparat penegak hukum yang progresif.

\section{DAFTAR PUSTAKA}

\section{Jurnal}

[1] Al-Azhar, H. F. (2019). "Rekonstruksi Konseptual Peradilan sebagai Revitalisasi Kekuasaan Kehakiman dalam Sistem Ketatanegaraan Indonesia". Volksgeist: Jurnal Ilmu Hukum dan Konstitusi, 2 (1).

[2] Ali, M. (2007). "Sistem Peradilan Pidana Progresif; Alternatif dalam Penegakan Hukum Pidana". Jurnal Hukum Ius Quia Iustum, 14 (2). DOI: https://doi.org/10.20885/iustum.vol14.iss2.art2

[3] Ansori, L. (2018). "Reformasi Penegakan Hukum Perspektif Hukum Progresif”. Jurnal Yuridis, 4 (2). DOI: http://dx.doi.org/10.35586/.v4i2.244

[4] Arrsa, R. C. (2014). "Rekonstruksi Politik Hukum Pemberantasan Korupsi Melalui Strategi Penguatan Penyidik Dan Penuntut Umum Independen KPK". Jurnal Rechts Vinding: Media Pembinaan Hukum Nasional, 3 (3).

[5] Ghonu, I. (2015). "Independensi Kejaksaan Dalam Sistem Peradilan Pidana Di Indonesia". Justitia Et Pax, 31 (2). DOI: https://doi.org/10.24002/jep.v31i2.1342

[6] Jainah, Z. O. (2011). "Membangun Budaya Hukum Masyarakat Penegak Hukum dalam Pemberantasan Tindak Pidana Narkotika". Keadilan Progresif, 2 (2).

[7] Muhammad, M. (2019). "Pemeriksaan Kepala Daerah Yang Terlibat Dalam Tindak Pidana Korupsi". Jurnal Yustitia, 18 (1).

[8] Muhammad, R. (2009). "Kemandirian Pengadilan Dalam Proses Penegakan Hukum Pidana Menuju Sistem Peradilan Pidana Yang Bebas Dan Bertanggung Jawab”. Jurnal $\begin{array}{llllll}\text { Hukum IUS } & \text { QUIA IUSTUM, } & 16 & \text { (4). DOI: }\end{array}$ https://doi.org/10.20885/iustum.vol16.iss4.art2 
[9] Muntaha, M. (2017). "Pengaturan Praperadilan dalam Sistem Hukum Pidana di Indonesia”. Mimbar Hukum-Fakultas Hukum Universitas Gadjah Mada, 29 (3).

[10]Pilok, D. F. (2013). "Kedudukan Dan Fungsi Jaksa Dalam Peradilan Pidana Menurut Kuhap". Lex Crimen, 2 (4).

[11]Rosita, D. (2018). "Kedudukan Kejaksaan Sebagai Pelaksana Kekuasaan Negara di Bidang Penuntutan dalam Struktur Ketatanegaraan Indonesia". Jurnal Ius Constituendum, 3 (1). DOI: http://dx.doi.org/10.26623/jic.v3i1.862

[12] Saputra, F., Kalo, S., Mulyadi, M., \& Hamdan, M. (2014). “Analisis Yuridis Penerbitan Surat Perintah Penghentian Penuntutan oleh Kejaksaan Dikaitkan dengan Asas Oportunitas dan Undang-undang No 16 Tahun 2004 Tentang Kejaksaan RI”. USU Law Journal, 2 (1).

[13] Sigar, K. S. (2017). "Kemandirian Kejaksaan Dalam Sistem Ketatanegaraan Republik Indonesia (Kajian UU No. 16 Tahun 2004)”. Lex Et Societatis, 5 (5).

[14] Sumakul, A. E. (2018). "Independensi Kejaksaan Dalam Melakukan Penyidikan Tindak Pidana Korupsi Menurut Undang-Undang Nomor 31 Tahun 1999 Jo. Undang-Undang Nomor 20 Tahun 2001". Lex Crimen, 7 (5).

[15] Warganegara, D. (2017). "Implementasi Konsep Hukum Progresif Dalam Penegakan Hukum Oleh Kepolisian Di Indonesia”. Poenale: Jurnal Bagian Hukum Pidana, 5 (3).

[16]Widodo, J. P. (2012). "Reformasi Sistem Peradilan Pidana dalam Rangka Penanggulangan Mafia Peradilan". Jurnal Dinamika Hukum, 12 (1).

[17] Windari, R. A. (2011). "Penegakan Hukum Terhadap Perlindungan Anak Di Indonesia (Kajian Normatif Atas Bekerjanya Hukum Dalam Masyarakat)". Media Komunikasi FPIPS, 10 (1). DOI: http://dx.doi.org/10.23887/mkfis.v10i1.1174

[18] Yusyanti, D. (2015). "Strategi Pemberantasan Korupsi Melalui Pendekatan Politik Hukum, Penegakan Hukum Dan Budaya Hukum”. E-Journal Widya Yustisia, 1 (1).

\section{Buku}

[19]Anwar Yesmil \& Adang. (2011). Sistem Peradilan Pidana. Bandung: Widya Padjadjaran.

[20]Arief, B. N. (2017). RUU KUHP Baru Sebuah Restrukturisasi/Rekonstruksi Sistem Hukum Pidana Indonesia. Semarang: Badan Penerbit Universitas Diponegoro.

[21] Arief, B. N. (2019). Kapita Selekta Hukum Pidana Tentang Sistem Peradilan Pidana Terpadu. Semarang: Bahan Penerbit Universitas Diponegoro.

[22] Arief. B. N. (2019). Reformasi Sistem Peradilan Sistem Penegakan Hukum Di Indonesia. Semarang: Bahan Penerbit Universitas Diponegoro.

[23] Kristiana Yudi. (2011). Independensi Kejaksaan dalam Penyidikan Korupsi. Bandung: Citra Aditya Bakti.

[24] Pujiyono. (2012). Rekonstruksi Sistem Peradilan Pidana Indonesia. Semarang: Penerbit Pustaka Magister.

[25] Satjipto Rahardjo, (2011). Satjipto Rahardjo Dan Hukum Progresif Urgensi Dan Kritik. Jakarta: Epistema Institue.

\section{Online/World Wide Web dan Lain-Lain}

[26] Medistiara, Yulida - detikNews, Deretan Jaksa yang Malah Diadili Karena Kasus Korupsi, diakses pada tanggal 6 Juni 2020 dalam https://news.detik.com/berita/d4994630/deretan-jaksa-yang-malah-diadili-karena-kasus-korupsi

[27] Teubner, G. (Ed.). (2011). Dilemmas of law in the welfare state. Walter de Gruyter. 